\title{
Chemical and Biological Leaching Methods to Remove Heavy Metals from Sewage Sludge: A Review
}

\author{
L.N. Ukiwe ${ }^{a}$, Allinor J.I ${ }^{b}$, Ejele A.E ${ }^{c}$, Anyadiegwu C.I.C ${ }^{d}$, Ibeneme S.I ${ }^{e}$ \\ ${ }^{\mathrm{a}, \mathrm{b}, \mathrm{c}}$ Department of Chemistry, Federal University of Technology, Owerri, Nigeria \\ ${ }^{\mathrm{d}}$ Department of Petroleum Engineering, Federal University of Technology, Owerri, Nigeria \\ ${ }^{\mathrm{e}}$ Department of Geosciences, Federal University of Technology, Owerri, Nigeria \\ Corresponding author: luggil2002@yahoo.com
}

\begin{abstract}
The removal of heavy metals (HMs) in sewage sludge (SS) is important since sludge is often disposed or applied on farmland to enhance soil fertility. The present study reviewed two conceptual approaches (chemical and biological leaching) of removing HMs present in SS. In the chemical leaching method, traditional acid treatment together with novel methods such as aeration, complexation and sequential extraction procedure have been reviewed extensively. Certain factors influence the removal of HMs in SS. These factors include; $\mathrm{pH}$, leaching agent, redox potential, and contact time. Nitric acid $\left(\mathrm{HNO}_{3}\right)$, hydrochloric acid $(\mathrm{HCl})$, sulphuric acid $\left(\mathrm{H}_{2} \mathrm{SO}_{4}\right)$, phosphoric acid $\left(\mathrm{H}_{3} \mathrm{PO}_{4}\right)$, ethylenediamine tetraacetic acid (EDTA), as well as Thiobacillus thiooxidans and Thiobacillus ferrooxidans are the most widely studied leaching agents and substrates involved in the chemical and bioleaching processes. However, the bioleaching process has been proposed as a safe, efficient, economical, environmental friendly method to remove HMs in SS due to its simplicity, high yield of metal extraction, low acid consumption, and low sludge solids concentration. Nevertheless, the present review has noted that most researchers are of the opinion that more studies are needed in the bioleaching method in order to enhance its commercial attraction.
\end{abstract}

\section{Indexing terms/Keywords}

acid, concentration, digestion, environment, extraction, organic, sludge

\section{Academic Discipline And Sub-Disciplines}

Environmental chemistry

\section{SUBJECT CLASSIFICATION}

Chemistry

TYPE (METHOD/APPROACH)

Literary Analysis

\section{Council for Innovative Research}

Peer Review Research Publishing System

\section{Journal: Journal of Advances in Chemistry}

Vol. 4, No. 3

editor@cirworld.com 


\section{Introduction}

Heavy metals (HMs) are members of elements that exhibit metallic properties with high atomic number and atomic weight as well as a specific gravity greater than 5.0. HMs includes the transition metals, some metalloids, lanthanides, and actinides. They are toxic and pose a threat to both humans and the ecosystem when their occurrence in the environment exceeds acceptable limits (1), (2). The main threats to human health from HMs are associated with exposure to elements such as lead $(\mathrm{Pb})$, mercury $(\mathrm{Hg})$, iron $(\mathrm{Fe})$, copper $(\mathrm{Cu})$, manganese $(\mathrm{Mn})$, cadmium $(\mathrm{Cd})$, arsenic $(\mathrm{As})$, nickel (Ni), aluminum (Al), silver (Ag), chromium (Cr), and beryllium (Be) (3). Most HMs originates in sewage sludge (SS).

Sewage sludge (SS) is commonly a cloudy dilute aqueous solution containing mineral and organic matter. SS also include domestic waste, human excreta, industrial effluents, and rubbish garden wastes. Most cases of water pollution are caused by SS. If SS is not treated or partially treated and it is directly discharged into water bodies, such water systems would thus be polluted (4). SS treatment is the process of removing contaminants such as HMs in wastewaters (5). There are two main types of SS, namely;

a) Coagulated SS: This is SS with a gelatinous appearance containing high concentrations of aluminum or iron salts with a mixture of organic and inorganic materials and hydroxide precipitates.

b) Soft SS: This is sludge containing mainly calcium carbonate and magnesium hydroxide precipitates with little organic and inorganic substances (5).

An important characteristic of SS is how the substance is to be treated. If the sludge is to be thickened by gravity, its settling and compaction rate are important. But if the sludge is to be digested anaerobically, the concentration of volatile compounds, other organic solids, as well as HMs are taken into consideration. In the design of SS handling and disposal operations, variability of the sludge is considered in terms of three 'Laws' namely; (6)

1. No two wastewater sludge are alike in all respect.

2. Sludge characteristics change with time.

3. There is no such sludge as average sludge.

The above laws define proper conditioning of SS. Sludge conditioning is a process whereby sludge is treated with chemicals or various other means to prepare it for dewatering process (6). Sludge conditioning make use of chemicals whose main function is either to lower or raise the $\mathrm{pH}$ value of the sludge such that smaller particles coagulate to larger ones to releasing water (7). The dewatered sludge and the coagulate are then digested separately using a leaching process.

Leaching is a process aimed at extracting a substance from a substrate through percolation by dissolving the substrate in a liquid medium either in nature or through an industrial process (7). In the chemical industry, leaching is also known as extraction (7). HMs are extracted from SS through the following processes;

i. Chemical leaching with inorganic and organic acids.

ii. Bioleaching with bacteria.

iii. Phyto-leaching; a passive treatment system using plants.

iv. Electro-kinetic leaching; treatment process of applying electric current.

v. Ultrasonic leaching; a treatment process using sound waves.

\subsection{Chemical leaching}

A major approach proposed to leach HMs from SS using chemicals involve a pretreatment step where the $\mathrm{pH}$ of the sludge is adjusted to 1-2 to promote solubilization of HMs (8). When acids are added to sludge, the HMs present in the sludge dissolves and exists in solution. This is a proton-exchange process. Physical separation steps are then applied to

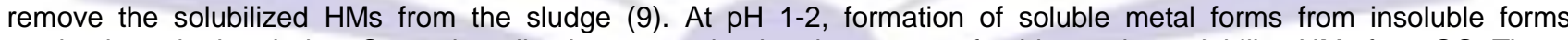
predominate in the sludge. Several studies have examined various types of acids used to solubilize HMs from SS. These studies include Fytianos et al. (10) who used hydrochloric acid $(\mathrm{HCl})$, Naoum et al. (11) who also tried nitric acid $\left(\mathrm{HNO}_{3}\right)$, and Cheung (12) who investigated the leaching of $\mathrm{HMs}$ from SS using sulphuric acid $\left(\mathrm{H}_{2} \mathrm{SO}_{4}\right)$. However, Yoshizaki and Tomida (13) examined the application of phosphoric acid $\left(\mathrm{H}_{3} \mathrm{PO}_{4}\right)$ in solubilizing HMs from SS. In further studies, Ukiwe and Iwu (14) indicated that it is possible to achieve maximum HMs solubilization if appropriate conditions of acids and contact time are applied. The authors noted that the concentration of $\mathrm{HMs}(\mathrm{Ni}$ and $\mathrm{Pb}$ ) was found to be highest when solubilization was performed at a contact time of $1 \mathrm{~h}$ using $\mathrm{HNO}_{3}$ and acetic acid. Ito et al. (15) had observed that hydrogen peroxide $\left(\mathrm{H}_{2} \mathrm{O}_{2}\right)$ is an effective leaching agent for solubilization of $\mathrm{Cu}$ and $\mathrm{Cr}$ from sludge. Chemical leaching of $\mathrm{HMs}$ using inorganic coagulants has been further examined by several researchers. In one study, two inorganic coagulants (aluminum sulphate; $\mathrm{Al}_{2}\left(\mathrm{SO}_{4}\right)_{3}$ ) and calcium oxide; $\mathrm{CaO}$ ) were applied to extract $\mathrm{HMs}$ from soil leachate. Results obtained indicated that $\mathrm{Al}_{2}\left(\mathrm{SO}_{4}\right)_{3}$ and $\mathrm{CaO}$ combined were able to extract $\mathrm{Cd}$ more than any other metal studied at $\mathrm{pH}$ 2.0-5.0. However, the study revealed that $\mathrm{Cu}$ was the least extracted heavy metal (HM) (16). Samrani et al. (17) investigated the effect of ferric chloride $\left(\mathrm{FeCl}_{3}\right)$ and polyaluminum chloride in $\mathrm{HMs}$ removal from sludge. The authors concluded that effective HMs removal was achieved with lower optimum dosage using polyaluminum chloride. In a related study, Zazouli and Yousefi (18) determined HMs concentration in raw leachate and observed that the removal efficiency of HMs with $\mathrm{FeCl}_{3}$ was economical and cost effective than that of $\mathrm{Al}_{2}\left(\mathrm{SO}_{4}\right)_{3}$. Okamoto (19) maintained that mobility and availability of $\mathrm{HMs}$ in sludge should be analyzed to establish its harmless application to agricultural land. Using calcium hydroxide $\left(\mathrm{Ca}(\mathrm{OH})_{2}\right)$ as leaching liquid, Okamoto (19) observed pronounced increase in $\mathrm{Zn}$ and Cd removal, and a slight removal ratio of $\mathrm{Ni}$ and $\mathrm{Cu}$ in digested sludge. It has been reported that the binding ability of HMs in sludge varies with application 
of coagulants as leaching fluid (20). Studies revealed that varying the amount of silicate/aluminum oxides resulted in either decrease or increase of the leaching contents of $\mathrm{Cu}$ and $\mathrm{Pb}$. Park and Yoon (21) in an earlier study had suggested that weighted coagulant additives are economical alternative to treat HMs in storm-water runoff.

Novel methods for chemical leaching of HMs from SS include aeration as well as aeration combined with acidification. Recently published studies have revealed that $\mathrm{Cu}$ and $\mathrm{Mn}$ were the highest metals extracted using aeration before acidification and aeration after acidification protocols, respectively (22). Some researchers have proposed that to achieve effective HMs mobilization and solubilization in sludge, the aeration and acidification process must be applied (23). In the opinion of these authors, mobility and bioavailability of metals depended on the chemical forms of the metal; hence, it is necessary to determine metal speciation first before evaluating the amount of metals leached from the sludge (23). Evidence has been accumulating to suggest that the aeration process increase the amount of $\mathrm{Cu}$ released from organically bound labile substrate (24). Besides HMs removal, optimizing the aeration process can considerably remove total nitrogen content in digested sludge (25). Other studies have indicated that HMs are effectively removed from SS when aeration and composting are practiced together (26). Related contributions on HMs removal from SS using aeration include studies by (27) and (28). Moreover, reports indicate that maximum HMs solubilization has been achieved when the appropriate conditions of acids and contact time have been applied (29). Kuo et al. (29) noted that a leaching time as high as $18 \mathrm{~h}$ extracted about $78 \% \mathrm{Cu}$ using inorganic acids such as $\mathrm{HNO}_{3}$ acid. However, other authors (30), (31), and (32) have suggested contact times of 2-6 $\mathrm{h}$ as period of optimum HMs solubilization using traditional inorganic acids. In an attempt to investigate the extraction of certain HMs from SS using different acid types, Gaber et al. (33) observed that at $\mathrm{pH} 2.43$, citric acid appear to be highly effective in extracting $\mathrm{Cu}(86 \%)$ and $\mathrm{Zn}(88 \%)$ in $24 \mathrm{~h}$ and 90 and $96 \%$ of $\mathrm{Cr}$ and $\mathrm{Ni}$, respectively in 5 days leaching (contact) time. However, compared to inorganic acids, the authors also observed removal rate of $82,89,88$ and $86 \%$ of $\mathrm{Cu}, \mathrm{Zn} \mathrm{Cr}$, and $\mathrm{Ni}$, respectively, in just $1 \mathrm{~h}$ leaching time. In spite of this resounding success by inorganic acid in extracting HMs from SS, the authors are of the opinion that organic acids are attracting attention as HMs extracting agents due to their mild acidic condition, biodegradability, and environmental friendly characteristics. The following studies, (34) and (35) have extensively documented evidence showing that $\mathrm{H}_{2} \mathrm{SO}_{4}$ is effective in solubilizing $\mathrm{Cu}$ and $\mathrm{Pb}$ from $\mathrm{SS}$, and (36) reported that the acid is a preferred leaching agent in removing $\mathrm{Fe}$, $\mathrm{Ni}, \mathrm{Cr}$, and $\mathrm{Cd}$ in contaminated waste streams. In further studies, Bouda et al. (37) compared the leaching efficiency of three oxidizing agents namely; $\mathrm{H}_{2} \mathrm{O}_{2}, \mathrm{FeCl}_{3}$, and ferric sulphate $\left(\mathrm{Fe}_{2}\left(\mathrm{SO}_{4}\right)_{3}\right)$ and observed that satisfactory metal removal yield of the three oxidants was linked to the effects of $\mathrm{pH}$ and/or redox potential. Nonetheless, Devil et al. (38) adopted another approach of chemical leaching of metals using single extraction process. The study noted that waste activated sludge (WAS) process is an advance sludge treatment method for HMs removal from wastewater. It was demonstrated that thermal hydrolysis and Fenton's peroxidation are two advance sludge treatment methods applied successfully in reducing HMs from sludge. In the opinion of Rozada et al. (39), chemical activation with zinc chloride $\left(\mathrm{ZnCl}_{2}\right)$ followed by pyrolysis was able to reduce $\mathrm{HMs}$ in sludge in the following order $\mathrm{Hg}>\mathrm{Pb}>\mathrm{Cu}>\mathrm{Cr}$, while Beauchesne et al. (40) in their contribution revealed that $\mathrm{H}_{2} \mathrm{SO}_{4}, \mathrm{FeCl}_{3}$, and $\mathrm{H}_{2} \mathrm{O}_{2}$ were effective in leaching $\mathrm{HMs}$ from sludge only when conditions such as $\mathrm{pH}$ and redox potential were adopted. However, Andrés and Francisco (41) concluded that acid column experiments were able to remove $\mathrm{Fe}, \mathrm{Mn}, \mathrm{Zn}$, and $\mathrm{Pb}$ from mine tailing sludge, while $\mathrm{Cu}$ and $\mathrm{Ni}$ were effectively mobilized. Natural zeolites such as clinoptilolite have been reported to take up and remove HMs from SS composting using ion exchange process. Fractionation of the HMs occurred during thermophilic and maturation phase of the removal process (42)

Complexing agents and organic acids have been tested successfully to extract/enhance the extraction of HMs from SS Studies by Veeken and Hamelers (43) have shown that application of citric and oxalic acids effectively removed HMs from sludge. Chelates such as ethylene-diamine tetraacetic acid (EDTA), ethylene-diamine disuccinic trisodium salt (EDDS), and diethylenetriamine pentacetic acid (DTPA) have been reported to increase metal solubility and influence their extraction yield in wastewaters. A notable contribution by Ukiwe et al. (44) observed that Cd was effectively extracted from digested sludge at $\mathrm{pH} 2.0$ using EDTA to enhance the removal efficiency of $\mathrm{HNO}_{3}$ as leaching agent. EDTA has also been demonstrated to give high removal yield of $\mathrm{Fe}, \mathrm{Ni}$, and $\mathrm{Cd}$ (45). Addition of EDTA to sludge also alters the stability of organo-mineral complexes and redox potential of the sludge enabling high rates of extraction of $\mathrm{Pb}(46)$. Polettini et al. (47) argued that in the presence of multiple contaminants, the use of single extraction agent is insufficient for optimum removal of HMs from polluted systems. The authors however suggested that if a single extraction agent is to be applied to de-pollute streams having multiple contaminants, then the application of complexing agents such as EDTA must be added to enhance the removal rate of the contaminants. Notwithstanding these recognized studies, researchers however warn that several factors should be considered before applying chelating agents to decontaminate HMs from sludge. These factors among many others include; the type and ratio of chelating agent to HMs in sludge. It has been reported that high concentration of chelating agents alters soil/sludge nutrient content and availability (47). Also, applying smaller quantities of chelating agents generates competition of chelates with other complexing substances found in the sludge. So moderate application of complexing agents is important for optimum removal of HMs from SS. Metals present in sludge remain in the labile fraction of the sludge mainly due to the presence of organic matter in the system (48). Metals found in the organic matter fraction are more readily available for mobilization, and consequently, more susceptible to bind with chelating agents (49). EDTA has a low solubility rate in soil (50). EDDS has been demonstrated to overcome the problems of low solubility in soil by EDTA. EDDS is more effective than EDTA in extracting metals from sludge due to its high biodegradability (50). Revealing studies by Raskin and Ensley (51) and Pigozzo et al. (52) have observed that EDDS and DTPA have been used successfully to enhance the removal rates of $\mathrm{Pb}, \mathrm{Cd}, \mathrm{Ni}$. $\mathrm{Zn}$, and $\mathrm{Cu}$ from contaminated waste streams. Further studies on EDTA leaching efficiency by Liphadzi and Kirkham (53) revealed that the substance is capable of mobilizing most HMs and increase their concentration in drainage water with or without plants. In separate studies, Turek et al. (54) and Peñalosa et al. (55) had noted that HMs extraction from SS is effective only when sodium salt of EDTA (EDTA-Na) is applied as a leaching agent. Peñalosa et al. (55) added that EDTA and nitrilotriacetic acid (NTA) were more efficient than malates and citrates in solubilizing metals ( $\mathrm{Fe}, \mathrm{Mn}, \mathrm{Cu}, \mathrm{Zn}$, and $\mathrm{Cd}$ ) from contaminated 
sludge with minimum differences between the two complexing agents. Researchers believe that the solubility and exchangeability of $\mathrm{HMs}$ such as $\mathrm{Zn}$ depend on the $\mathrm{pH}$ of the sludge (56). At $\mathrm{pH}$ less than 5.0, it has been observed that citric acid addition lowered the solubility of $\mathrm{Zn}$ and favored its exchangeability. The study further revealed that $\mathrm{pH}$ was the dominant factor in influencing the cation exchange capacity of the sludge, hence altering redistribution and exchangeability of HMs in the sludge.

Literature reports have been published suggesting that the sequential extraction procedure (SEP), though controversial, is being recognized as a modern chemical leaching technique to remove HMs from sludge. An original research paper by $\mathrm{Kao}$ et al. (57) observed that application of SEP to determine chemical speciation of $\mathrm{Cd}, \mathrm{Cr}, \mathrm{Pb}, \mathrm{Ni}$, and $\mathrm{Zn}$ in $\mathrm{SS}$ demonstrated that extraction of $\mathrm{Zn}$ dominated the oxide fraction, while $\mathrm{Pb}$ and $\mathrm{Zn}$ were concentrated in the residual fraction. The study, however, noted that $\mathrm{Cu}$ was the only heavy metal (HM) that dominated the organic fraction of the sludge. Speciation is a process aimed at easy determination of HMs in sludge. The metals must be made available through a physical fractionation process. SEP is frequently used to fractionate HMs in sludge. The theory behind SEP is such that the more mobile metals are removed in the first fraction and metal extraction continues in the order of decreasing mobility (58). All SEPs facilitate fractionation of metals. Tessier et al. (59) gave these fractions as; exchangeable, carbonate bound, Fe and Mn oxide bound, organic matter bound, and residual. Some authors re-named these fractions as; exchangeable, weakly absorbed, hydrous-oxide bound, organic bound, and lattice material components, respectively (60). Using the SEP developed by (59) to evaluate evolution of HM speciation during the aerobic composting process of SS, Liu et al. (61) reported that the concentration of $\mathrm{Pb}, \mathrm{Zn}$, and $\mathrm{Cd}$ in the residual fraction decreased but that of $\mathrm{Ni}$ and $\mathrm{Cr}$ increased. In a separate study, Okamoto (19) observed that the SEP was effective in processing $\mathrm{HMs}$ into seven fractions with $\mathrm{Ni}, \mathrm{Zn}$, and $\mathrm{Cd}$ mainly dominating the carbonate fraction, while $\mathrm{Cu}$ occurred mainly in the exchangeable fraction. Investigating variations of HMs distributions during SS composting, a notable research (62) indicated that $\mathrm{Mn}$ and $\mathrm{Zn}$ were mainly found in the exchangeable and carbonate fraction, while $\mathrm{Pb}$ was strongly associated with the organic matter fraction. The study further revealed that the mobility (bioavailability) of metals increased during the composting process. It has been documented that the SEP is effective to determine the chemical forms of $\mathrm{Ni}, \mathrm{Cu}, \mathrm{Cr}, \mathrm{Pb}$, and $\mathrm{Zn}$ in SS (63). Metal partitioning and distribution in the residue was also found to be different after acid treatment of the sludge (63). Amir et al. (64) observed that by applying the SEP to determine HMs in sludge, about $80 \%$ of the HMs were found in the residual fraction, while $\mathrm{Zn}$ and $\mathrm{Cu}$ were present in the organic and carbonate fractions, respectively. Further studies using SEP have been published by Arain et al. (65) who compared different extraction approaches for HM partitioning in sediment samples, and Shan and Chen (66) who also applied the SEP to evaluate speciation of trace metals in model soil containing natural minerals and humic acid. Researchers are still divided on the effectiveness of the SEP in HMs extraction from sludge. Some researchers believe that the SEP is still a limited HMs extraction scheme since it is complex, time consuming, and not well understood in the scientific world (67). Despite this fact, most scientist agree that incorporating ultrasound accelerated extraction (UAE) to the SEP reduce the extraction time and provide detailed understanding of the partitioning behavior of HMs in SS (67). The present review is of the opinion that more research is needed in the application of the SEP in determining precisely the speciation, distribution, mobilization, and solubilization of HMs in SS.

\subsection{Biological leaching}

Bioleaching is the extraction of specific metals from their ores through the use of bacteria (68). Both living and dead cells as well as products derived from or produced by microorganisms could be effective metal accumulators (68). Bioleaching aim, especially, at solubilizing HMs with subsequent reduction in concentration of pathogens in the sludge (69). This is possible in that extreme $\mathrm{pH}$ condition is obtained in the sludge during the bioleaching process (69). Bioleaching make use of naturally occurring bacteria in reactors to oxidize sulphide or ferrous ion. The key point is that the bacteria oxidizes metals present in the sludge in 3-5 days when they are provided with optimal operating and living conditions in reactors. Over the years, the bioleaching technique has evolved as an efficient, economical, environmental friendly method of removing HMs in SS. When ferrous ion is used, ferric ion is produced as the oxidized product which acts as an oxidant causing solubilization of metals (70).

Substrate concentration and solids content of the sludge play an important role in determining the effectiveness of the bioleaching process. High sludge solids concentration of the sludge interferes with $\mathrm{pH}$ reduction due to high buffering capacity of the sludge, hence, reducing metal solubilization. However, decrease $\mathrm{pH}$ value of the sludge is associated with an increase in the oxidation-reduction potential of the sludge which is an indicator of substantial growth of the bioleaching microorganisms (71). Dozens of bacteria species have been identified as having bioleaching capabilities. Those of commercial interest include species of Thiobacillus, Leptospirillum, Sulphurbacillum, and Sulphurlobus (5). Thiobacillus ferrooxidans is an aerobic rod-shaped microorganism that derives its energy from the oxidation of various sulphide minerals and soluble ferrous ion. It thrives in acidic environment of $\mathrm{pH} 1-3$. T. ferrooxidans and T. thiooxidans are the two most useful bacteria of commercial interest in bioleaching (72), (73). Desirable qualities such as simplicity, high yield of metal extraction, low acid and alkali consumption, and minimal reduction in sludge nutrients such as nitrogen and phosphorus, have made bioleaching a choice procedure of researchers in decontaminating SS (74).

Removing HMs from SS by bioleaching (mainly by sulphur and iron-oxidizing bacteria) have been the interest of many investigators. Tyagi et al. (75) noted that bioleaching of HMs using sulphur-oxidizing bacteria is less expensive than traditional chemical leaching methods using acids. The principle behind sulphur-oxidizing bioleaching is that elemental sulphur is added to the sludge and it is oxidized by mixed sulphur-oxidizing bacteria present as substrate in sludge to sulphuric acid (76). This action lowers the $\mathrm{pH}$ of the sludge from near 7.0 to about 1.2. Solubilization of metals in the sludge occurs at $\mathrm{pH}$ 1.2. Most bacteria in the sludge are thus destroyed at this $\mathrm{pH}$ level. The lower $\mathrm{pH}$ of the sludge also contributes to reduction of volatile organic matter in the sludge (76). An investigation into the effect of sludge solids 
concentration on bioleaching of HMs from tannery sludge by indigenous sulphur-oxidizing bacteria observed that after 25 days of bioleaching, the $\mathrm{pH}$ of the sludge was reduced to 1.3 , while about $87,73,72,62$, and $73 \%$ of $\mathrm{Cr}, \mathrm{Al}, \mathrm{Fe}, \mathrm{Mg}$, and $\mathrm{Zn}$, respectively, were leached out of the sludge. The study further maintained that the leaching efficiencies of $\mathrm{Cr}$, Al, and Fe for both the chemical and bioleaching processes were similar at $\mathrm{pH} 1.3(77)$. T. thiooxidans has been shown of being capable to oxidize sulphur in digested sludge while decreasing the $\mathrm{pH}$ value from 5.5 to 1.5 . (78). A study by (78) indicated that insoluble metal sulphides could be solubilized through $T$. thiooxidans acidification of sludge. Pathak et al. (79) examined the effects of sulphur concentration, initial $\mathrm{pH}$ of sludge, and sludge solid content on metal bioleaching using anaerobically digested SS and observed that 86 and $44 \%$ of $\mathrm{Zn}$ and $\mathrm{Cr}$, respectively, were bioleached from the sludge. Shanableh and Ginige (80) also evaluated the use of natural sulphur-oxidizing bacteria in sludge and reported that 97,98 , $71,4,3$, and $91 \%$ of $\mathrm{Ni}, \mathrm{Pb}, \mathrm{Cr}, \mathrm{Cu}, \mathrm{Cd}$, and $\mathrm{Zn}$, respectively, were leached from the sludge. The study concluded that $\mathrm{Ni}$ and $\mathrm{Pb}$ were the easiest metals to be leached, while $\mathrm{Cu}$ and $\mathrm{Cd}$ were the most difficult metals leached from the sludge. Recent studies by Fang et al. (81) has reported removal rates of $99 \%$ of $\mathrm{Zn}$ from sludge linked to a microbial consortia leaching process comprising sulphur-oxidizing bacteria and bioprecipitation. In a related study, Lee et al. (82) examined metal removal using bioleaching driven by injection of sulphur-oxidizing bacteria, $T$. thiooxidans. The bioleaching process was sequentially integrated with electro-kinetic soil process. When the final removal efficiency of HMs of the combined process was compared with those of individual processes, it was observed that the bioleaching process was a good pretreatment step to mobilize HMs in sludge. Bioleaching using $T$. thiooxidans has been extensively researched in published studies by the following authors, (83), (84), (85), (86), (87), and (88).

The application of iron-oxidizing bacteria (Thiobacillus ferrooxidans) in bioleaching of HMs has been shown to be a promising technique for de-polluting contaminating systems. The effect of two types of substrates $\left(\mathrm{Fe}^{2+}\right.$ and $\left.\mathrm{S}^{0}\right)$ and their combination on metal removal efficiencies was studied using $T$. ferrooxidans. Results obtained showed inoculation of $T$. ferrooxidans and co-addition of $\mathrm{Fe}^{2+}$ and $\mathrm{S}^{0}$ accelerated $\mathrm{pH}$ reduction and metal solubilization with removal efficiencies of 80 and $100 \% \mathrm{Cr}$ and $\mathrm{Cu}$ (89). A related study investigating the bioleaching of HMs from dewatered SS using T. ferrooxidans observed that higher removal efficiency of HMs were obtained when sludge-adapted cells, addition of inorganic nutrients, and lower sludge content were involved in the bioleaching process (90). However, in a separate contribution, Bayat and Sari (91) observed decreased leaching efficiencies of HMs with increasing pulp density when $T$. ferrooxidans was used to remove HMs in dewatered metal plating sludge. Effects of organics such as yeast have been shown to influence the ability of $T$. ferrooxidans in bioleaching of metals (92). A recent study noted that the presence of yeast in sludge decreased the proportion of $T$. ferrooxidans thereby reducing the rate of bioleaching of metals. Lee et al. (93) reasoned that other bacteria such as Geobacter metallireducens possess bioleaching activity. The authors reported that $G$. metallireducens is a metal-reducing microorganism that has been tested successfully for bioleaching of HMs, but concluded that for commercial use as a remediation technology, more studies are needed on the microbe to ascertain in detail its multilateral evaluation as an effective bioleaching agent. Further investigations using $T$. ferrooxidans have come to light in the studies of bioleaching of metal concentrates of waste printed circuit boards by mixed culture bacteria (94), and the effect of introducing exogenous strain $T$. thiooxidans on functional gene expression of indigenous bacteria consortia (95). More advances on the application of $T$. ferrooxidans as a bioleaching agent are reported in studies by (96), (97), (98), and (99). Effectiveness of mixed culture of both sulphur and iron-oxidizing bacteria in bioleaching of HMs have been demonstrated by Zhao et al. (100) and Chan et al. (101). Both studies agreed that both iron and sulphur-oxidizing bacteria achieved efficient removal rates of $\mathrm{HMs}$ from sludge, especially, with recalcitrant metals such as $\mathrm{Cu}$ and $\mathrm{Cr}$. However, the authors noted that the iron-oxidizing process had a faster removal rate of HMs than the sulphur-oxidizing system.

\section{Conclusion}

A review of chemical and biological leaching processes to remove HMs from SS has been undertaken in the present study. In the chemical leaching process, it was revealed that acids are added to sludge to solubilize the HMs present in the sludge. Parameters such as $\mathrm{pH}$, redox potential, acid type, contact time, and air influence the ability of acids to solubilize $\mathrm{HMs}$ in sludge. Inorganic acids such as $\mathrm{HNO}_{3}, \mathrm{HCl}, \mathrm{H}_{2} \mathrm{SO}_{4}$, and $\mathrm{H}_{3} \mathrm{PO}_{4}$ are common leaching agents that have been applied successfully in the chemical leaching process. Complexing agents such as EDTA, DTPA, and NTA as well as organic acids (citric, oxalic, malic acids) have been reported to be effective in the chemical leaching of metals. However, SEP and aeration are novel procedures in chemical leaching of HMs that are beginning to gain wide public acceptance.

Nevertheless, in the biological leaching method, it was observed that $T$. thiooxidans and $T$. ferrooxidans are the two most studied bacteria of commercial interest in the leaching of HMs from contaminated systems. In-as-much-as the bioleaching scheme has been propounded by many authors as a safe, efficient, environmental friendly method of removing HMs from SS, most researchers are of the opinion that more studies are required to establish its commercial significance. 


\section{REFERENCES}

1. Duffus, J.H. Heavy metals a meaningless term? Pure and Applied Chemistry, (2002), 74: 793-807.

2. Wahab, A., Ahmed S., \& Ameer, M.F. The environmental impact of gold mines: pollution by heavy metals. Central European Journal of Engineering, (2011), 2: 304-313.

3. Hossn, E., Mokhtar, G., El-Awady M., Ali, I, Morsy, M., \& Dawood, A. Environmental exposure of the pediatric age groups in Cairo city and its suburbs to cadmium pollution. Science of the Total Environment, (2001), 273: 135-146.

4. Sharma, B.K. Engineering chemistry. ( $5^{\text {th }}$ Edn.). Meerut, India: Kriskna Prakashan Media Ltd., (2002). pp 143148.

5. Marchioretto, M.M., Bruning, H., Loan, N.T., \& Rulkens, W.H. Heavy metals extraction from anaerobically digested sludge. Water Science and Technology, (2002), 46: 1-8.

6. Weiner, R.F., \& Matthew, R.A. Environmetal engineering. (4 ${ }^{\text {th }}$ Edn.). New Delhi, India: Elsevier, (2007). pp 207210.

7. Ask.com. What is the defination of leaching. (2013), Available online: http://www.ask.com/question

8. Babel, S., \& Dacera, D.M. Heavy metal removal from contaminated sludge for land application. A review. Waste Management, (2006), 26: 988-1004.

9. Ukiwe, L.N. \& Oguzie, E.E. Effect of $\mathrm{pH}$ and acid on heavy metal solubilization of domestic sewage sludge. Terrestrial and Aquatic Environmental Toxicology, (2008), 2: 54-58.

10. Fytianos, K.., Charantoni, E., \& Voudrias, E. Leaching of heavy metals from municipal sewage sludge. Environmental International, (1998), 24: 467-475.

11. Naoum, C., Fatta, D., Haralambous, K.J., \& Loizidou, M. Removal of heavy metals from sewage sludge by acid treatment. Journal of Environmental Science and Health, (2001), A36: 873-881.

12. Cheung, Y.H. Acid treatment of anaerobically digested sludge: effect of heavy metal content and dewaterability. Environmental International, (1988), 14: 553-561.

13. Yoshizaki, S., \& Tomida, T. Principle and process of heavy metal removal from sewage sludge. Environmental Science and Technology, (2000), 34: 1572-1575.

14. Ukiwe, L.N., \& Iwu, I.C. Effect of aeration time and acids in chemical leaching of heavy metals in sewage sludge. Terrestrial and Aquatic Environmental Toxicology, (2010), 5: 73-76.

15. Ito, A., Takahashi, K., Aizawa, J., \& Umita, T. Enhanced heavy metals removal without phosphorus loss from anaerobically digested sewage sludge. Water Science and Technology, (2008), 58: 201-206.

16. Ukiwe, L.N., \& Nwoko, C.I.A. The influence of acids and $\mathrm{pH}$ in removal efficiency of heavy metals by inorganic coagulants. Terrestrial and Aquatic Environmental Toxicology, (2010), 5: 65-68.

17. Samrani, E.A.G, Lartiges, B.S., \& Villieras, F. Chemical coagulation of combined sewer overflow: Heavy metal removal and treatment optimization. Water Research, (2008), 951-960.

18. Zazouli, M.A., \& Yousefi, Z. Removal of heavy metals from solid wastes leachate coagulation-flocculation process. Journal of Applied Sciences, (2008), 8: 2142-2147.

19. Okamoto, T. Studies on the agriculture use of limed sewage sludge changes in form and behaviour of some heavy metal as affected by soil $\mathrm{pH}$ with long term application of the sludge. Bulletin of the Agricultural Research Institute of Kanagawa Prefecture, (2004), 146: 1-73.

20. Xu, G., Zou, J., \& Li, G. Stabilization/solidification of heavy metals in sludge ceramsite and leachability affected by oxide substances. Environmental Science and Technology, (2009), 43: 5902-5907.

21. Park, S.J., \& Yoon, T.I. Weighted coagulation with glass and diatomite for storm-water treatment and sludge disposal. Environmental Engineering Science, (2003), 20: 307-317.

22. Ukiwe, L.N., \& Nwoko, C.I.A. Effect of aeration and acidification on heavy metal solubilization of sewage sludge. Terrestrial and Aquatic Environmental Toxicology, (2010), 5: 69-72.

23. Loska, K., \& Wiechufa, D. Effects of $\mathrm{pH}$ and aeration on copper migration in above-sediment water. Polish Journal of Environmental Studies, (2006), 9: 433-437.

24. Gerring, L.J.A. Mobility of $\mathrm{Cu}, \mathrm{Cd}, \mathrm{Ni}, \mathrm{Pb}, \mathrm{Zn}, \mathrm{Fe}$, and $\mathrm{Mn}$ in marine sediment slurries under anaerobic conditions and at 20\% air saturation. Netherlands Journal of Sea Research, (1991), 27: 145-151.

25. Parravicini, V., Svardal, K., Hornek, R., \& Kroiss, H. Aeration of anaerobically digested sewage sludge for COD and nitrogen removal: optimization at large-scale. Water Science and Technology, (2008), 57: 257-264.

26. Sanna, K.M., Kari, H., \& Jukka, A.R. Removal of DEHP in composting and aeration of sewage sludge. Chemosphere, (2003), 54: 265-272.

27. Attar, M.H., Bina, B., \& Moeinian, K. Effects of aeration rate and detention time on thermophilic aerobic digestion of mixed sludge and its dewaterability. International Journal of Environmental Science and Technology, (2005), 2 : 111-114.

28. Smidta, E., \& Parravicini, V. Effect of sewage sludge treatment and additional aerobic post-stabilization revealed by infrared spectroscopy and multivariate data analysis. Bioresource Technology, (2009), 100: 1775-1780.

29. Kuo, C.Y., Wu, C.H., \& Lo, S.L. Leaching efficiency of copper from industrial sludge with traditional acid extraction (TAE) and microwave assisted treatment (MAT). Journal of Environmental Science and Health, (2005), A40: 2203-2214.

30. Abeh, T., Gungshik, J., \& Adamu, M.M. Speciation studies of trace elements levels in sediments from Zaramaganda stream, Jos, Nigeria. Journal of Chemical Society of Nigeria, (2007), 32: 218-225.

31. Nwajei, G.E., \& Iwegbue, C.M.A. Trace metal concentration in soils in the vicinity of Uwelu motor spare parts market, Benin City, Nigeria. Journal of Chemical Society of Nigeria, (2007), 32: 282-286. 
32. Nwajei, G.E., \& Iwegbue, C.M.A. Heavy metals in dust particles from selected laboratories in Delta State University, Abraka, Nigeria. Journal of Chemical Society of Nigeria, (2007), 32: 287-291.

33. Gaber, S.E., Rizk, M.S., \& Yehia, M.M. Extraction of certain heavy metals from sewage sludge using different types of acids. Biokemistri, (2011), 23: 41-48.

34. Jenkins, R.L., Scheybeler, B.J., Smith, M.L., Baird, R., Lo, M.P., \& Haug, R.T. Metal removal and recovery from municipal sludge. Journal (Water Pollution Control Federation), (1981), 53: 25-28.

35. Chino, M., Moriyama, K., Saito, H., \& Morn, T. The amount of heavy metals derived from domestic sources in Japan. Water, Air, \& Soil Pollution, (1991), 57: 829-837.

36. Lasheen, M.R., Ashmawy, A., \& Ibrahim, H. Heavy metals removal from municipal and industrial sludges. (2013), Available online: http://www.cprm.gov.br

37. Bouda, M., Hammy, F., Mercier, G., \& Blais, J. Chemical leaching of metals from wastewater sludge: comparative study by use of three oxidizing agents $\left(\mathrm{H}_{2} \mathrm{O}_{2}, \mathrm{FeCl}_{3}\right.$, and $\left.\mathrm{Fe}_{2}\left(\mathrm{SO}_{4}\right)_{3}\right)$. Water Environment Research, (2009), 81: 523-531.

38. Dewil, R., Baeyens, J., \& Neyens, E. Reducing the heavy metal content of sewage sludge by advanced sludge treatment methods. Environmental Engineering Science, (2006), 23: 994-999.

39. Rozada, F., Otero, M., Morán, A., \& García, A.I. Adsorption of heavy metals onto sewage sludge-derived materials. Bioresource Technology, (2008), 99: 6332-6338.

40. Beauchesne, I., Ouarda, T., \& Blais, J.F. Optimization of a sewage sludge chemical decontamination process. (2007), Available online: http://www.bvsde.paho.org

41. Andrés, N.F., \& Francisco, M.S. Effects of sewage sludge application on heavy metal leaching from mine tailings impoundments. Bioresource Technology, (2008), 99: 7521-7530.

42. Zorpas, A.A., Inglezakis, V.J., \& Loizidou, M. Heavy metals fractionating before, during and after composting of sewage sludge with natural zeolite. Waste Management, (2008), 28: 2054-2060.

43. Veeken, A.H.M., \& Hamelers, H.V.M. Removal of heavy metals from sewage sludge by extraction with organic acids. Water Science and Technology, (1999), 40: 129-136.

44. Ukiwe, L.N., Nwoko, C.I.A., \& Nkwocha, E.E. Heavy metals solubilization in EDTA assisted remediation of sewage sludge. Terrestrial and Aquatic Environmental Toxicology, (2010), 5: 47-50.

45. Samanidou, V., \& Fytianos, K. Mobilization of heavy metals. Water, Air, and Soil Pollution, (1990), 52: $217-225$.

46. Pereira, B.F.F., Anreu, C.A., Romeiro, S., Lagia, A.M.M., \& Gonzalez, A.P. Pb phytoextraction in a Pb-EDTA treated oxisol. Science Agriculture, (2007), 64: 52-60.

47. Polettini, A., Pomi, R., \& Galcagnoli, G. Assisted washing for heavy metal and metalloid removal from contaminated dredged materials. Water, Air, and Soil Pollution, (2008), 196: 183-198.

48. Galdos, M.V., Maria, I.C., \& Camargo, O.A. Soil chemical properties and corn production in a sewage amended soil. Revista Brasileira de Ciência do Solo, (2004), 28: 569-577.

49. Coscione, A.R., Abreu, C.A., \& Santos, G.C. Chelating agents to solubilize heavy metals from oxisols contaminated by the addition of organic and inorganic residues. Science Agrilculture, (2009), 66: 103-106.

50. Tandy, S., Bossart, K., Mueller, R., Ritschel, J., Hauser, L., Schulin, R., \& Nowach, B. Extraction of heavy metals from soils using biodegradable chelating agents. Environmental Science and Technology, (2004), 38: 937-944.

51. Raskin, I., \& Ensley, B.D. Phytoremediation of toxic metals; using plants to clean up the environment. ( $3^{\text {rd }}$ Edn.). New York, USA: John Wiley, (2000). p 365.

52. Pigozzo, A.T., Lenzi, E., Junior, J.L., Scapin, C.A., \& Costa, A.C. Transition metal rates in latosol twice treated with sewage sludge. Brazilian Archives of Biology and Technology, (2006), 49: 515-526.

53. Liphadzi, M.S., \& Kirkham, M.B. Heavy metal deplacement in EDTA-assisted phytoremediation of biosolids soil. Water Science and Technology, (2006), 54: 147-153.

54. Turek, M., Korolewicz, T., \& Ciba, J. Removal of heavy metals from sewage sludge used as soil fertilizer. Soil \& Sediment Contamination, (2005), 14: 143-154.

55. Peñalosa, J.M., Carpena, R.O., Vázquez, S, Agha, R., Granado, A., Sarro, M.J., \& Esteban, E. Chelate-assisted phytoextraction of heavy metals in a soil contaminated with a pyritic sludge. Science of the Total Environmental, (2007), 378: 199-204.

56. Munsuk, Y.S., \& Bruce, J.R. Zinc exchangeability as a function of $\mathrm{pH}$ in citric acid-amended soils. Soil Science, (2003), 168: 356-367.

57. Kao, P.H., Huang, C.C., \& Hseu, Z.Y. Chemical speciation and phytotoxicity of heavy metals in sewage sludge for the germination of chinese cabbage seeds. Terrestrial and Aquatic Environmental Toxicology, (2007), 1: 1-6.

58. Zimmerman, A.J., \& Weindorf, D.C. Heavy metal and trace metal analysis in soil by sequential extraction: $A$ review of procedures. International Journal of Analytical Chemistry, (2010), 2010: 1155-1162.

59. Tessier, A., Campbell, P.G.C., \& Blsson, M. Sequential extraction procedure for the speciation of particulate trace metals. Analytical Chemistry, (1979), 51: 844-851.

60. Maiz, I., Arambarri, I., Garcia, R., \& Millán, E. Evaluation of heavy metals availability in polluted soils by two sequential extraction procedures using factor analysis. Environment Pollution, (2000), 110: 3-9.

61. Liu, Y., Ma, L., Li, Y., \& Zheng, L. Evolution of heavy metal speciation during the aerobic composting process of sewage sludge. Chemosphere, (2007), 67: 1025-1032.

62. Nomeda, S., Valdas, P., Chen, S.Y., \& Lin, J.G. Variations of metal distribution in sewage sludge composting. Waste Management, (2008), 28: 1637-1644.

63. Stylianou, M.A., Kollia, D., Haralambous, K.J., Inglezakis, V.J., Moustakas, K.G., \& Loizidou, M.D. Effect of acid treatment on the removal of heavy metals from sewage sludge. Desalination, (2007), 215: 73-81.

64. Amir, S., Hafidi, M., Merlina, G., \& Revel, J.C. Sequential extraction of heavy metals during composting of sewage sludge. Chemosphere, (2005), 59: 801-810. 
65. Arain, M.B., Kazi, T.G., Jamali, M.K., Baig, J.A., Afridi, H.I., Jalbani, N., \& Sarfraz, R.A. Comparison of different extraction approaches for heavy metals partitioning in sediment samples. Pedosphere, (2009), 19: 476-485.

66. Shan, X.Q., \& Chen, B. Evaluation of sequential extraction for speciation of trace metals in model soil containing natural minerals and humic acid. Analytical Chemistry, (1993), 65: 802-807.

67. Iwegbue, C.M.A., Emuh, F.N., Isirimah, N.O., \& Egun, A.C. Fractionation, characterization and speciation of heavy metals in composts and compost-amended soils. African Journal of Biotechnology, (2007), 6: 67-78.

68. Gadd, G.M. Heavy metal accumulation by bacteria and other microorganisms. Cellular and Molecular Life Sciences, (2005), 46: 834-840.

69. Lombardi, A.T., \& Garcia, J.O. An evaluation into the potential of biological processing for the removal of metals from sewage sludges. Critical Reviews in Microbiology, (1999), 25: 275-288.

70. Pathak, A., Dastidar, M.G., \& Sreekrishnan, T.R. Bioloeaching of heavy metals from sewage sludge using indigenous iron-oxidizing microorganism: effect of substrate concentration and total solids. World Academy of Science, Engineering and Technology, (2009), 58: 525-530.

71. Couillard, D., Chartier, M., \& Mercier, G. Bacterial leaching of heavy metals from aerobic sludge. Bioresource Technology, (1991), 36: 293-302.

72. Cho, K.S., Ryu, H.W., \& Moon, H.S. Effects of sludge solid and S amount on the bioleaching of heavy metals from sewage sludge using sulphur oxidizing bacteria. Journal of Korean Society of Environmental Engineering, (1999), 21: 433-442.

73. Wong, J.W.C., Xiang, L., Gu, X.Y., \& Zhou, L.X. Bioleaching of heavy metals from anaerobically digested sewage sludge using FeS as an energy source. Chemosphere, (2004), 55: 101-107.

74. Tyagi, C. Microbial leaching of removing heavy metals from sewage sludge with Acidithiobacillus species. Journal of Environmental Sciences and Technology, (2001), 32: 751-759.

75. Tyagi, R.D., Couillard, D., \& Tran, F.T. Heavy metal removal from anaerobically digested sludge by a chemical and microbiological methods. Environmental Pollution, (1988), 50: 295-310.

76. Blais, J.F., Tyagi, R.D., \& Auclair, J.C. Bioleaching of metals from sewage sludge by sulphur-oxidizing bacteria. Journal of Environmental Engineering, (1992), 118: 690-707.

77. Shen, S.B., Tyagi, R.D., Blais, J.F., \& Surampalli, R.Y. Bacterial leaching of metals from tannery sludge by indigenous sulphur-oxidizing bacteria-Effect of sludge solids concentration. Journal of Environmental Engineering, (2003), 129: 513-519.

78. Schönborn, W., \& Hartmann, H. Bacterial leaching of metals from sewage sludge. Applied Microbiology and Biotechnology, (2004), 5: 305-313.

79. Pathak, A., Dastidar, M.G., \& Sreekrishnan, T.R. Bioleaching of heavy metals from anaerobically digested sewage sludge. Journal of Environmental Science and Health, (2008), A43: 402-411.

80. Shanableh, A., \& Ginige, P. Acidic bioleaching of heavy metals from sewage sludge. Journal of Material Cycles and Waste Management, (2000), 2: 43-50.

81. Fang, D., Zhang, R., Zhou, L., \& Li, J. A combination of bioleaching and bioprecipitation for deep removal of contaminating metals from dredged sediment. Journal of Hazardous Materials, (2011), 192: 226-233.

82. Lee, K.Y., Kim, H.A., Lee, B.T., Kim, S.O., Kwon, Y.H., \& Kim, K.W. A feasibility study on bioelectrokinetics for the removal of heavy metals from tailing soil. Environmental Geochemistry and Health, (2011), 1: 3-11.

83. Zhang, P., Zhu, Y., Zhang, G., Zou, S., Zeng, G., \& Wu, Z. Sewage sludge bioleaching by indigenous sulphuroxidizing bacteria: Effects of ratio of substrate dosage to solid content. Bioresource Technology, (2009), 100: 1394-1398.

84. Chen, Y.X., Hua, Y.M., Zhang, S.H., \& Tian, G.M. Transformation of heavy metal froms during sewage sludge bioleaching. Journal of Hazardous Materials, (2005), 123: 196-202.

85. Jain, D.K., \& Tyagi, R.D. Leaching of heavy metals from anaerobic sewage sludge by sulphur-oxidizing bacteria. Enzyme Microbial Technology, (1992), 14: 376-383.

86. Shen, S.B., Vidyararthi, A., Tyagi, R.D., Surampalli, R.Y., \& Blais, J.F. Bacterial leaching of metals from tannery sludge by indigenous sulphur-oxidizing bacterial-Effect of sulphur concentration. Practical Periodicals of Hazardous, Toxic and Radioactive Waste Management, (2002), 6:244-249.

87. Tyagi, R.D. Microbial leaching of metals from municipal sludge:Effect of sludge solids concentration. Process Biochemistry, (1992), 27: 89-96.

88. Tyagi, R.D., Blais, J.F., Meunier, N., \& Benmoussa, H. Simultanous sewage sludge digestion and metal leachingEffect of sludge solids concentration. Water Research, (1997), 31: 105-118.

89. Zhou, S.G., Zhou, L.X., \& Fang, D. Enhancing metal removal by coaddition of $\mathrm{Fe}^{2+}$ and $\mathrm{S}^{0}$ as substrates of Acidithiobacillus ferrooxidans for sewage sludge bioleaching. Practical Periodicals of Hazardous, Toxic and Radioactive Waste Management, (2008), 12: 159-165.

90. Kim, I.S., Lee, J.U., \& Jang, A. Bioleaching of heavy metals from dewatered sludge by Acidithiobacillus ferrooxidans. Journal of Chemical Technology and Biotechnology, (2005), 80: 1339-1348.

91. Bayat, B., \& Sari, B. Comparative evaluation of microbial and chemical leaching processes for heavy metal removal from dewatered metal plating sludge. Journal of Hazardous Materials, (2010), 174: 763-769.

92. Li, Q., Tian, Y., Fu, X., Yin, H., Zhou, Z., Liang, Y., Qiu, G., Liu, J., Liu, H., Shen, L., Cong, J., \& Liu, X. The community dynamics of major bioleaching microorganisms during chalcopyrite leaching under the effects of organics. Current Microbiology, (2011), 63: 164-172.

93. Lee, K.Y., Bosch, J., \& Meckenstock, R.U. Use of metal-reducing bacteria for bioremediation of soil contaminated with mixed organic and inorganic pollutants. Environmental Geochemistry and Health, (2012), 34: 135-142. 
94. Zhu, N., Xiang, Y., Zhang, T., Wu, P., Dang, Z., Li, P., \& Wu, J. Bioleaching of metal concentrates of waste printed circuit boards by mixed culture of Acidophilic bacteria. Journal of Hazardous Materials, (2011), 192: 614619.

95. Liu, Y., Yin, H., Zeng, W., Liang, Y., Liu, Y., Baba, N., Qiu, G., Shen, L., Fu, X., \& Liu, X. The effect of the introduction of exogenous strain Acidithiobacillus thiooxidans A01 on functional gene expression, structure and function of indigenous consortium during pyrite bioleaching. Bioresource Technology, (2011), 102: 8092-8098.

96. Blais, J.F., Auclair, J.C., \& Tyagi, R.D. Cooperation between two Thiobacillus strains for heavy metal removal from municipal sludge. Canadian Journal of Microbiology, (1992), 38: 181-187.

97. Sreekrishnan, T.R., Tyagi, R.D., Blais, J.F., \& Campbell, P.G.C. Kinetics of heavy metals bioleaching from sewage sludge: Effects of process parameters. Water Research, (1993), 27: 1641-1651.

98. Tyagi, R.D., Couillard, D., \& Tran, F.T. Heavy metal removal from anaerobically digested sludge by a chemical and microbiological methods. Environmental Pollution, (1988), 50: 295-316.

99. Tyagi, R.D., Meunier, N., \& Blais, J.F. Simultaneous sewage sludge digestion and metal leaching-Effect of temperature. Applied Microbiology and Biotechnology, (1996), 46: 422-431.

100. Zhao, L., Zhu, N.W., \& Wang, X.H. Comparison of bio-dissolution of spent Ni-Cd batteries by sewage sludge using ferrous ions and elemental sulfur as substrate. Chemosphere, (2008), 70: 978-981.

101.Chan, L.C., Gu, X.Y., \& Wong, J.W.C. Comparison of bioleaching of heavy metals from sewage sludge using iron and sulfur-oxidizing bacteria. Advances in Environmental Research, (2003), 7: 603-607.

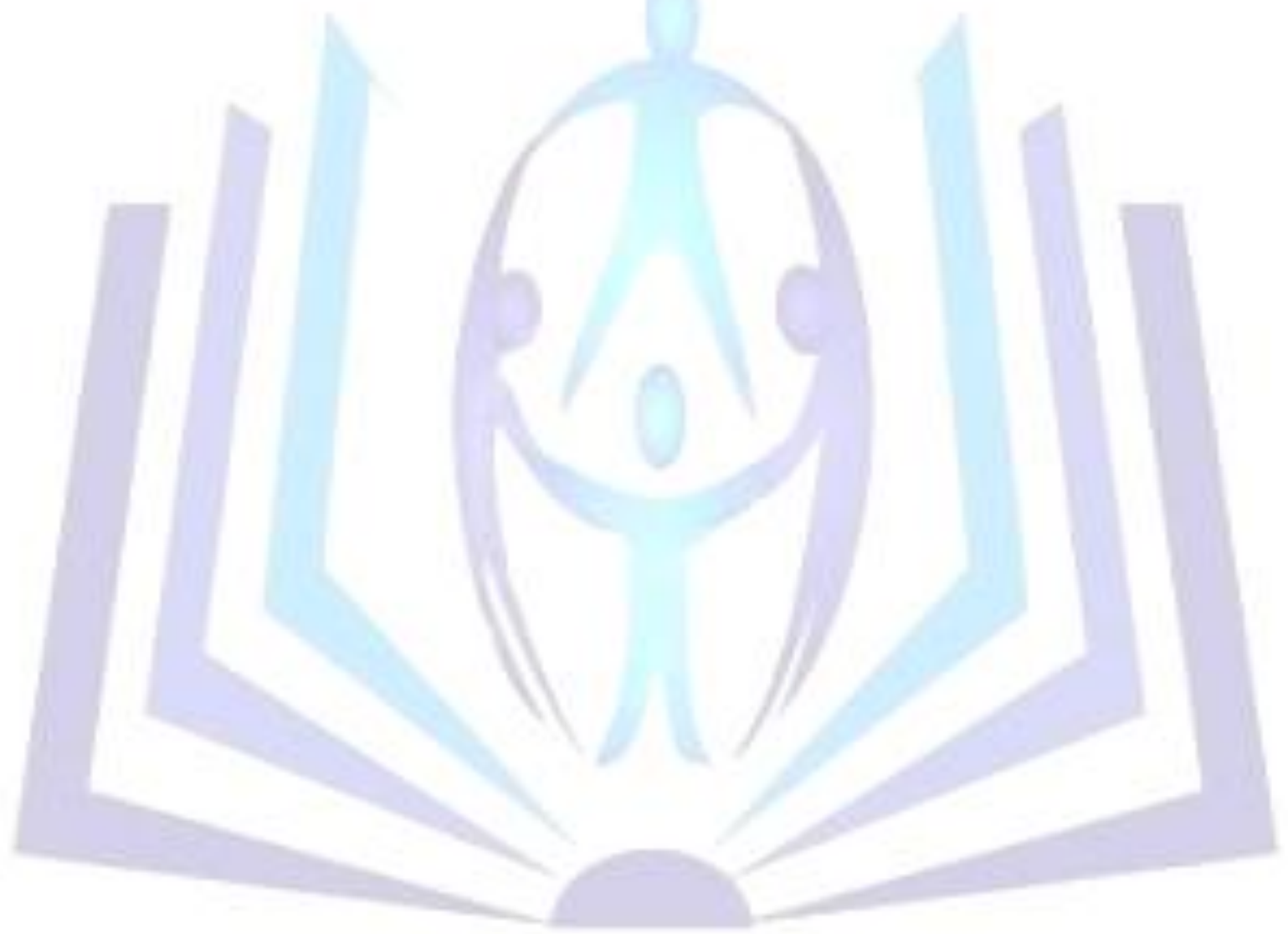

